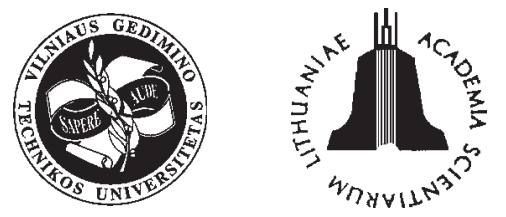

ISSN 1392-3730

JOURNAL OF CIVIL ENGINEERING AND MANAGEMENT

http:/www.jcem.vgtu.lt

2005, Vol XI, No 1, 3-12

\title{
PUSHOVER ANALYSIS OF ASYMMETRIC THREE-DIMENSIONAL BUILDING FRAMES
}

\author{
Rui Carneiro Barros ${ }^{1}$, Ricardo Almeida ${ }^{2}$ \\ ${ }^{1}$ Dept of Civil Engineering, University of Porto, Rua Roberto Frias, Porto 4200-465, Portugal. \\ E-mail: rcb@fe.up.pt \\ ${ }^{2}$ School of Technology, Politechnic Institute of Viseu, Viseu, Portugal. E-mail: ralmeida@estvipv.pt
}

Received 02 Dec 2004; accepted 28 Febr 2005

\begin{abstract}
The effect of higher modes of vibration on the total non-linear dynamic response of a structure is a very important and unsolved problem. To simplify the process the static non-linear pushover analysis was proposed associated with the capacity spectrum method, utilising a load pattern proportional to the shape of the fundamental mode of vibration of the structure. The results of the pushover analysis, with this load pattern, are very accurate for structures that respond primarily in the fundamental mode. But when the higher modes of vibration become important for the total response of the structure, this load pattern loses its accuracy. To minimise this problem a new multimode load pattern is proposed based on the relative participation of each mode of vibration in the elastic response of a structure subjected to an earthquake ground motion. This load pattern is applied to the analyses of symmetric frames as well as to stiffness asymmetric and mass asymmetric irregular building frames, under seismic actions of distinct orientations, permitting to draw significant conclusions.
\end{abstract}

Keywords: pushover analysis, multimode load pattern, non-linear dynamic analysis, asymmetric irregular structures.

\section{Introduction}

Inelastic time-history analysis is a powerful tool for the study of structural seismic response. A set of carefully selected ground motion records can give an accurate evaluation of the anticipated seismic performance of structures. Despite the fact that the accuracy and efficiency of the computational tools have increased substantially, there are still some reservations about the dynamic non-linear analysis, which are mainly related to its complexity for practical design applications. Since the non-linear dynamic analysis of building structures is not feasible for most practical applications, many researchers are trying to develop more rational analysis methods that would achieve a satisfactory balance between required reliability and applicability for everyday design use.

Many of these attempts suggest obtaining the main characteristics of the seismic behaviour with a non-linear static analysis under monotonically increasing loads (pushover analysis). The non-linear static pushover analysis is a simple option for estimating the strength capacity in the post-elastic range. This procedure involves applying a predefined lateral load pattern that is distributed along the building height.

The lateral forces are then monotonically increased in constant proportion with a displacement control in the top of the building, until a certain level of deformation is reached. The method allows tracing the sequence of yielding and failure of structural members, as well as the progress of the overall capacity curve of the structure.

The ATC-40 [1] and FEMA-273/274 [2] documents contain this simplified non-linear analysis procedure (pushover analysis) to determine the displacement demand imposed on the building expected to deform inelastically. The non-linear static procedure in these documents is based on the capacity spectrum method, and assumes that the lateral force distribution for the pushover analysis and the conversion of the results to the capacity diagram are based only on the fundamental vibration mode of the elastic structure. So, the pushover analysis is adequate for structures that vibrate predominantly in the fundamental mode. If higher modes are important, the pushover analysis can underestimate some response quantities.

The scope of this research is to evaluate the effect of the above-mentioned approximation in three dimensional asymmetric frame structures, for which the higher modes are important in the dynamic response of the structures.

For this type of structures a different lateral force distribution is proposed for the pushover analysis, based 
on a multimode combination of the vibration modes obtained from a linear elastic analysis of the structure. The performance of the proposed multimode load pattern is evaluated by comparing the results of the pushover analyses, with either the conventional lateral load proportional to the shape of the fundamental mode of vibration or the multimode load pattern, and the results obtained from the non-linear dynamic analysis of structures subjected to earthquake excitations in different directions.

\section{Non-linear dynamic analysis}

The dynamic analysis of non-linear systems is performed using direct numerical integration methods because analytical solution of the equations of motion of the system is usually not possible if the excitation - applied force $p(t)$ or ground acceleration $\ddot{u}(t)$ - varies arbitrarily with time or if the system is non-linear. So, such problems must be solved by numerical time-stepping methods for integration of the differential equations of motion. The time stepping procedures can be divided into two major groups: (1) the explicit methods and (2) the implicit methods.

\subsection{Implicit versus explicit procedures}

In the explicit methods the new state vector is obtained directly from the results of previous time instants. In the implicit methods a set of equations needs to be solved for the new state vector at instant $t_{\mathrm{n}+1}$.

The most popular explicit method is the central difference time integration procedure. This procedure is formulated from the central difference approximation for velocities and accelerations:

$$
\begin{gathered}
\dot{u}_{i}=\frac{u_{i+1}-u_{i-1}}{2 \Delta t}, \\
\ddot{u}_{i}=\frac{u_{i+1}-2 u_{i}+u_{i-1}}{(\Delta t)^{2}} .
\end{gathered}
$$

After considering the dynamic equilibrium equation this leads to a recursive algorithm.

For stability reasons explicit time integration procedures are restricted to very small time steps, which for many realistic analyses lead to a very large number of steps. The size of these time steps is typically so small that the aspects of accuracy are practically irrelevant; moreover, each of these steps is almost trivial when the mass matrix is diagonal. Explicit schemes are particularly suitable for structural dynamic problems where the participation of higher frequencies in the overall response is important, ie when structures are subjected to blast or shock loading giving rise to a wave propagation problem.

As explicit schemes rely essentially on extrapolations from an equilibrium state, it is hardly surprising that the size of the time step allowed must be restricted to be less than some critical value. The simplicity of the method also allows for the treatment of non-linear problems. No iterations are then required, as the solution at the new time instant again represents an extrapolation from the equilibrium conditions at the previous time instant. The inherent extrapolation nature of an explicit method may lead to an unacceptable accumulation of errors in the overall energy balance, especially for nonlinear problems.

Implicit procedures are very often made to be unconditionally stable, ie the solution can be obtained for the time step of any size, so that the accuracy arguments may pose an upper limit for the time step to be used. The accuracy arguments are associated with the physics of the problem considered, ie with the frequency of excitation and with the fundamental period of vibration. Each of the steps here is significantly more costly than in the case of an explicit scheme, as the algorithm requires a solution of a set of equations formulated at every time instant. For linear problems, and if the time step is kept constant, the factorisation of the effective stiffness matrix could be done only once; the recursive scheme implies effectively the solution for recursive effective right-hand side vectors of the equation of motion. In non-linear problems, ie involving plasticity, every time step is associated with a new effective stiffness matrix; iterations are required to ensure convergence for both dynamic equilibrium as well as for constitutive relations [3-6].

Unlike explicit methods, which for maximum efficiency rely on a relatively poor mass representation by adopting diagonal mass matrices and special starting algorithms, implicit methods do not suffer from any of these restrictions.

In the non-linear dynamic analysis performed in this research the implicit Newmark procedure was utilised [3] mainly because in the software used (ADINA) [7] the Newmark algorithm is made to be unconditionally stable.

\subsection{Implicit Newmark time integration procedure}

In 1959, N. M. Newmark developed a family of timestepping implicit methods based on the equations $[3,8]$ :

$$
\begin{gathered}
\dot{u}_{i+1}=\dot{u}_{i}+[(1-\gamma) \Delta t] \ddot{u}_{i}+(\gamma \Delta t) \ddot{u}_{i+1}, \\
u_{i+1}=u_{i}+(\Delta t) \dot{u}_{i}+\left[(0,5-\beta)(\Delta t)^{2}\right] \ddot{u}_{i}+ \\
{\left[\beta(\Delta t)^{2}\right] \ddot{u}_{i+1} .}
\end{gathered}
$$

The parameters $\beta$ and $\gamma$ define the variation of acceleration over a time step and determine the stability and accuracy characteristics of the method. A typical selection for these parameters that is satisfactory from all points of view, including that of accuracy, is: $\gamma=0,5$; $0,1(6) \leq \beta \leq 0,25$. These two equations, combined with the equilibrium equation (5) at the end of the time step, provide the basis for computing $u_{i+1}, \dot{u}_{i+1}$ and $\ddot{u}_{i+1}$ at time $i+1$ from the known $u_{i}, \dot{u}_{i}$, and $\ddot{u}_{i}$ at time $i$ : 


$$
m \ddot{u}+c \dot{u}+f_{S}(u, \dot{u})=p(t) .
$$

There are two very well-known special cases of the Newmark method, summarised on Table: average acceleration and linear acceleration methods [3, 8].

Average acceleration and linear acceleration methods

\begin{tabular}{|l|l|}
\hline AVERAGE ACCELERATION & \multicolumn{1}{|c|}{ LINEAR ACCELERATION } \\
\hline$u_{i+1}$ & $\ddot{u}(\tau)=\ddot{u}_{i}+\frac{\tau}{\Delta \Delta}\left(\ddot{u}_{i+1}-\ddot{u}_{i}\right)$ \\
$\dot{u}(\tau)=\frac{1}{2}\left(u_{i+1}+\ddot{u}_{i}\right)$ & $\dot{u}(\tau)=\dot{u}_{i}+\ddot{u}_{i} \tau+\frac{\tau^{2}}{2 \Delta t}\left(\ddot{u}_{i+1}-\ddot{u}_{i}\right)$ \\
$\dot{u}(\tau)=\dot{u}_{i}+\frac{\tau}{2}\left(\ddot{u}_{i+1}+\ddot{u}_{i}\right)$ & $\dot{u}_{i+1}=\dot{u}_{i}+\frac{\Delta t}{2}\left(\ddot{u}_{i+1}+\ddot{u}_{i}\right)$ \\
$\dot{u}_{i+1}=\dot{u}_{i}+\frac{\Delta t}{2}\left(\ddot{u}_{i+1}+\ddot{u}_{i}\right)$ & $u(\tau)=u_{i}+\dot{u}_{i} \tau+\ddot{u}_{i} \frac{\tau^{2}}{2}+\frac{\tau^{3}}{6 \Delta t}\left(\ddot{u}_{i+1}-\ddot{u}_{i}\right)$ \\
$u(\tau)=u_{i}+\dot{u}_{i} \tau+\frac{\tau^{2}}{4}\left(\ddot{u}_{i+1}+\ddot{u}_{i}\right)$ & $\left.u_{i+1}=u_{i}+\dot{u}_{i} \Delta t+(\Delta t)^{2} \mid \frac{1}{6} \ddot{u}_{i+1}+\frac{1}{3} \ddot{u}_{i}\right)$ \\
$u_{i+1}=u_{i}+\dot{u}_{i} \Delta t+\frac{(\Delta t)^{2}}{4}\left(\ddot{u}_{i+1}+\ddot{u}_{i}\right)$ & \\
\hline
\end{tabular}

\section{Pushover analysis}

Among engineers concerned with the development of seismic design procedures there is a general consensus that presently employed elastic design and analysis methods cannot capture many important phenomena that control seismic performance of structures in severe earthquakes. But the inelastic time-history analysis, although a very powerful technique, is still computationally expensive and not feasible for most practical applications.

The search for a more rational and transparent design process has been pursued for some time and will remain to be an issue of much debate and controversy for years to come. Design will always be a compromise between simplicity and reality; with the recognition that reality is very complex and uncertain in imposed demands and available capacities, and simplicity is a necessity driven by cost and the limited ability to implement complexity with commonly available knowledge and tools. The pushover analysis is by no means a final answer to the design/analysis problems, but it is a significant step forward by giving consideration to those inelastic response characteristics that will distinguish between good and bad performance in severe earthquakes.

The static pushover analysis is a partial and relatively simple intermediate solution to the complex problem of predicting force and deformation demands imposed on structures and their elements by severe ground motion.

The important terms are static and analysis. Static implies that a static method is being employed to represent a dynamic phenomenon; a representation that may be adequate in many cases but is doomed to failure sometimes. Analysis implies that a system solution has been created already and the pushover is employed to evaluate the solution and modify it as needed.
The pushover is part of an evaluation process and provides estimates of demands imposed on structures and elements. Evaluation implies that imposed demands have to be compared to available capacities in order to assess acceptability of the design. It $\mathrm{s}$ fair to say that at this time deformation capacities cannot be estimated with great confidence, not for new elements and less so for elements of existing structures. Recognising this limitation, the task is to perform an evaluation process that is relatively simple but captures the essential features that significantly affect the performance goal. It is in this context that research like the one carried is important, to improve the reliability and the quality of the method.

A simple example of a pushover analysis is illustrated in Fig 1. The two-dimensional frame shown could represent the lateral load resisting system for a steel perimeter frame structure.

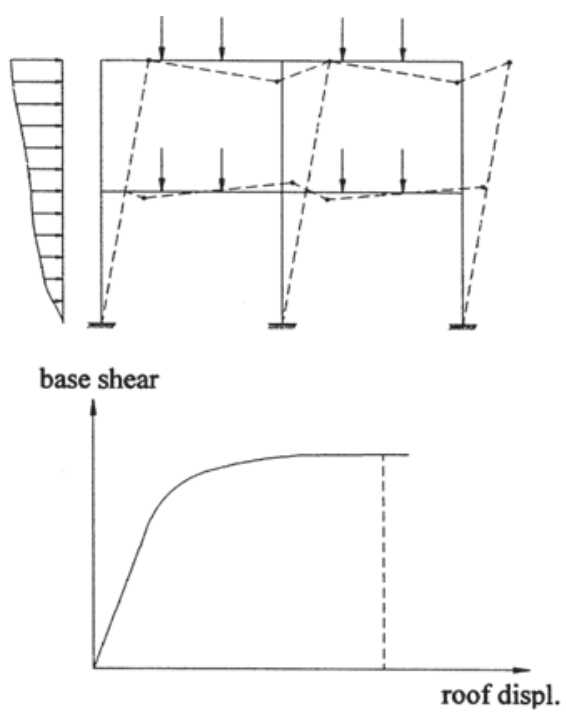

Fig 1. Illustration of a pushover analysis

The process is to represent the structure with a two or three-dimensional analytical model that accounts for all important linear and non-linear response characteristics, apply lateral loads in predetermined patterns that represent approximately the relative inertia forces generated at locations of substantial masses, and "push" the structure under these load patterns to specific target displacement levels. The internal forces and deformations computed at the target displacement levels are estimates of the strength and deformation demands, which need to be compared to available capacities.

The static pushover procedure has been presented and developed over the past twenty years by various researchers. The method is also described and recommended as a tool for design and assessment purposes by the National Earthquake Hazard Reduction Program (NEHRP, FEMA-273) guidelines [2] for the seismic rehabilitation of existing buildings and represents a main component of the Spectrum Capacity Analysis method (ATC-40) [1]. The Structural Engineers Association of 
California also accepted this technique (SEAOC, Vision 2000) [9] among other analysis procedures with various levels of complexity. This analysis procedure is selected for its applicability to performance-based seismic design approaches and can be used at different design levels to verify the performance targets. It is clear from recent discussions that this approach is likely to be recommended in future codes.

\section{The capacity spectrum method}

The non-linear static pushover analysis is a comprehensive method of evaluating earthquake response of structures explicitly considering non-linear behaviour of structure elements. The capacity spectrum method is one approach for implementing pushover analysis that compares structure capacity with ground shaking demand to determine peak response during an earthquake.

The capacity spectrum method estimates peak response by expressing both structure capacity and ground shaking demand in terms of spectral acceleration and displacement (hence the name capacity spectrum).

\subsection{Capacity and demand curves}

The capacity spectrum method of pushover analysis is essentially the same as any other method of pushover analysis, except for the determination of peak global response.

The capacity spectrum method assumes peak response of the non-linear structure to be equal to the modal displacement of an equivalent elastic system with an effective period, $T_{\text {eff }}$, based on secant stiffness, as shown in Fig 2.

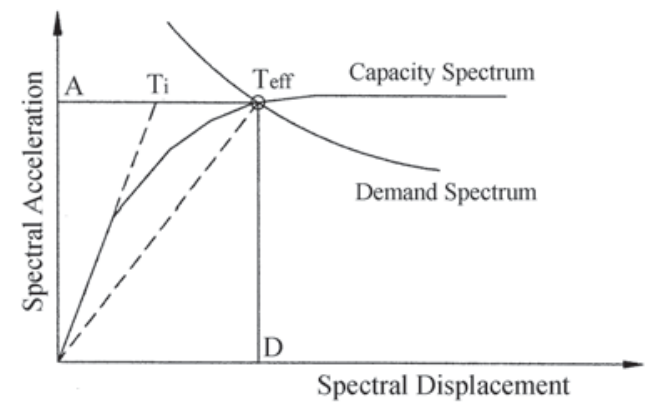

Fig 2. Capacity and demand spectra curves

The assumption of an equivalent linear system based on secant stiffness properties is used by other non-linear analysis procedures.

For example, this concept is the basis of procedures developed by Division 95 of the Los Angeles City Building Code [10] for evaluation of concrete frame buildings with masonry infill.

\subsubsection{The capacity curve}

The first step in the construction of capacity and demand spectra curves (shown in Fig 2) is the conversion of the pushover curve (eg, base shear vs roof displacement) to an equivalent capacity curve (eg, spectral acceleration vs spectral displacement).

Conversion of pushover to capacity begins with linearisation (using secant stiffness properties) of the nonlinear structure producing a pseudo-dynamic "pushover mode". The shape of pushover mode is, in general, an amplitude dependent since secant stiffness changes on amplitude. Ideally, the pushover curve should be linearised at the point of peak response (fully capturing non-linear effects). Fortunately, pseudo-dynamic properties of the pushover mode are typically stable and tend to be about the same at all amplitudes.

Fig 3 illustrates the conversion of a pushover curve to a capacity spectrum curve.

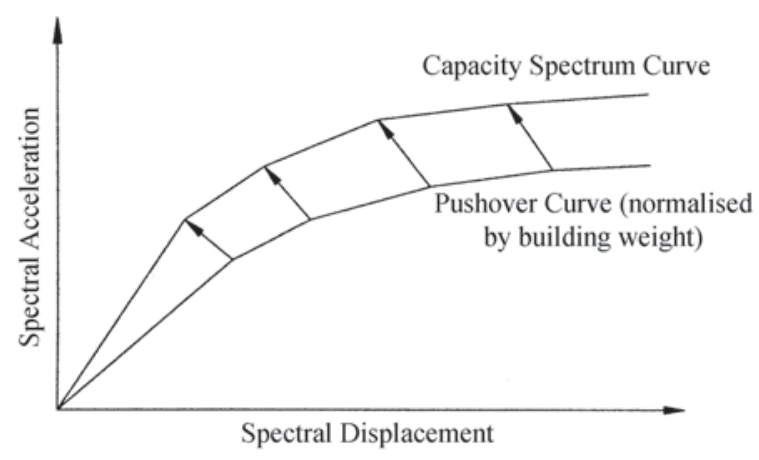

Fig 3. Pushover conversion to capacity

The formulas for conversion of a pushover curve to a capacity spectrum are identical to linear modal dynamic analysis equations, which would be used to convert base shear to modal force and to convert roof displacement to modal displacement. The only difference is the substitution of the pushover mode shape (eg, at the point of peak response) for a mode shape obtained from dynamic analysis. The equations for pushover conversion to capacity are given bellow:

$$
A=\frac{V / W}{\alpha_{1}},
$$

$$
D=\frac{\delta_{\text {roof }}}{\alpha_{2}},
$$

with

$$
\alpha_{1}=\frac{\left[\sum_{i=1}^{N} w_{i} \phi_{i}\right]^{2}}{W \sum_{i=1}^{N} w_{i} \phi_{i}^{2}},
$$




$$
\alpha_{2}=\phi_{\text {roof }} \frac{\sum_{i=1}^{N} w_{i} \phi_{i}}{\sum_{i=1}^{N} w_{i} \phi_{i}^{2}},
$$

where $\boldsymbol{A}$ - spectral acceleration at $D ; \boldsymbol{D}$ - spectral displacement; $\boldsymbol{V}$ - pushover base shear at $\boldsymbol{\delta}_{\text {roof }} ; \boldsymbol{\delta}_{\text {roof }}-$ pushover curve displacement; $\boldsymbol{\alpha}_{1}$ - fraction of mass in pushover mode; $\boldsymbol{\alpha}_{\mathbf{2}}$ - ratio roof/pushover mode displacement; $\boldsymbol{\Phi}_{\boldsymbol{i}}-$ pushover mode shape, at location $i ; \boldsymbol{\Phi}_{\text {roof }}-$ pushover mode shape, at roof; $\boldsymbol{w}_{\boldsymbol{i}}$ - tributary weight at location $i ; \boldsymbol{W}$ - total weight of the structure; $\boldsymbol{N}$ - number of discrete weight/pushover mode shape locations.

In the above equations, both $a_{1}$ and $a_{2}$ are equal to 1,0 when the pushover mode acts like a single degree of freedom system. In this case, the capacity spectrum curve is identical to the pushover curve.

\subsubsection{The demand curve}

The second step in the construction of capacity and demand spectra curves (shown in Fig 2) is the calculation of demand spectra from $5 \%$ damped design spectra. This calculation is based on a damping reduction factor that is a function of the effective damping associated with the capacity curve. In the capacity spectrum method, effective damping is defined by equivalent viscous damping of the pushover mode (based on secant stiffness). Effective damping represents all energy-dissipation mechanisms of the structure, considering both the amplitude and duration (number of cycles) of earthquake response.

In general, effective damping is amplitude dependent. Before reaching yield, effective damping is typically assumed to be $5 \%$ of critical, although this number could be greater depending on material type. Newmark and Hall [11] suggest other values of damping of structures at yield (or just bellow yield).

After reaching yield, effective damping tends to increase rapidly as the hysteretic behaviour of the elements dissipates energy during cyclic response. Of course, a substantial number of elements must reach yield, before there is a significant effect on the global response of the structure. Damping will tend to increase with the amplitude of the response (ie, hysteresis loop increases with amplitude), but may not be able to sustain this level of damping during repeated cycles of earthquake response (ie, hysteresis loop squeezes or otherwise degrades area).

Fig 4 illustrates effective stiffness and effective damping of the global structural system. In this figure, the above-mentioned properties are shown for the same capacity curve, but at different levels of response.

The first response level indicates slightly non-linear behaviour of the global structure, effective stiffness is about two-thirds of initial stiffness and effective damping is about 10 to $20 \%$ of critical.
The second response level indicates a more significant level of non-linear behaviour, effective stiffness is about one-half to one-third of the initial stiffness and damping is about 20 to $40 \%$ of critical. These values of damping assume no degradation of the hysteresis loop, ie, they correspond to a full loop area.
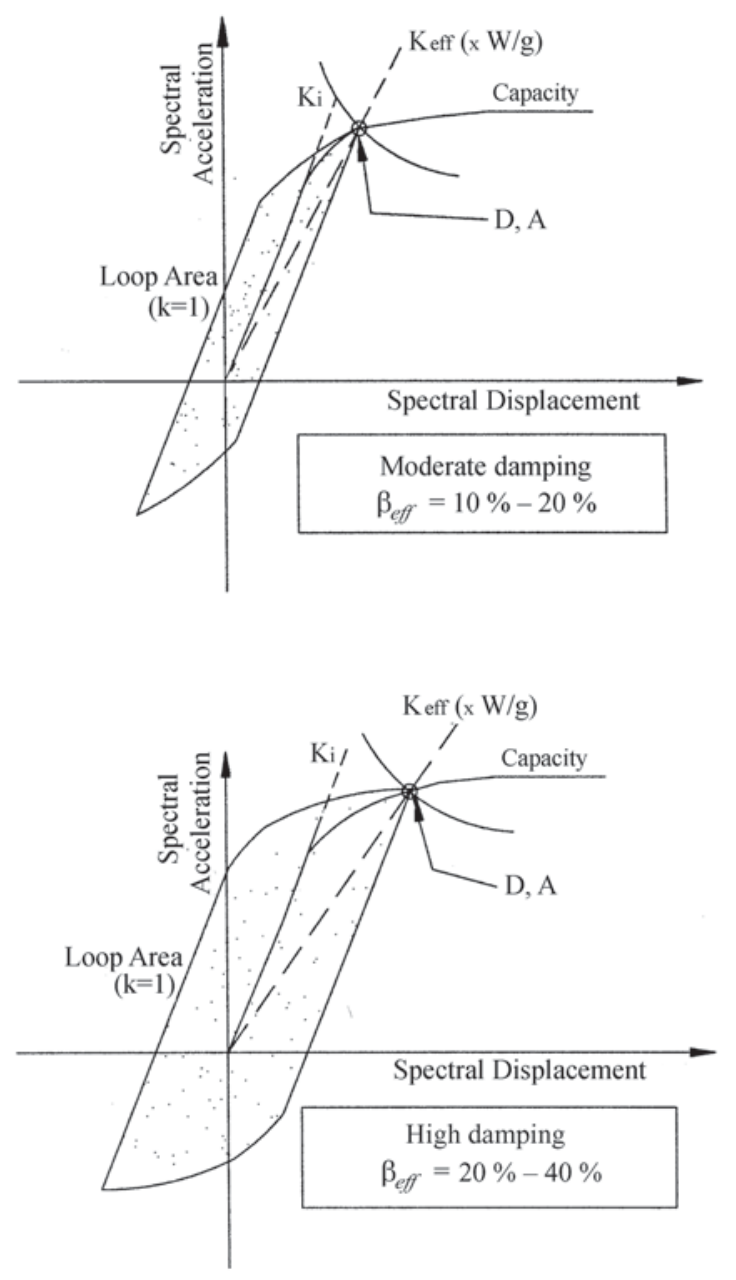

Fig 4. Example effective stiffness and damping

The equations for calculating effective stiffness and effective damping are given below:

$$
\begin{gathered}
K_{\text {eff }}=\frac{A}{D}\left(\frac{W}{g}\right), \\
\beta_{\text {eff }}=\frac{k}{2 \pi}\left(\frac{\text { Area }}{K_{\text {eff }} D^{2}}\right)+0,05,
\end{gathered}
$$

where $\boldsymbol{K}_{\text {eff }}$ - effective secant stiffness at displacement D; $\boldsymbol{\beta}_{\text {eff }}$ - effective viscous damping, fraction of critical, at displacement D; $\boldsymbol{A}$ - spectral acceleration at displacement D; $\boldsymbol{D}$ - spectral displacement; $\boldsymbol{W}$ - total building weight; $\boldsymbol{g}$ - gravity constant; Area - area enclosed by non-degraded hysteresis loop for one full cycle of response at displacement range $\pm \mathrm{D} ; \boldsymbol{k}$ - degradation factor used to reduce non-degraded area of hysteresis loop. 
The equation for calculating effective damping, $\beta_{\text {eff }}$, is based on the viscous representation of hysteretic damping, plus two modifications introduced by ATC-40 [1]. First, a nominal amount of viscous damping of $5 \%$ of critical is assumed to exist in addition to hysteretic damping. Thus, the damping equation always yields at a damping value of at least $5 \%$ of critical.

Second, a degradation factor $k$ is included in the damping equation to reduce the full (non-degraded) area of the hysteresis loop, when the duration of the earthquake is expected to affect the structure's ability to dissipate energy.

In case of no degradation, $k=1,0$. In the case of complete degradation, $k=0,0$ and $\beta_{\text {eff }}=0,05$.

The amount of reduction of $5 \%$-damped spectra associated with effective damping (above $5 \%$ of critical) is based on the median spectral amplification factors given by Newmark and Hall [11].

The damping reduction factors are a function of the period domain of response spectra. Short-period damping reduction factors, $\beta_{S}$, are as much as $50 \%$ greater (at very high damping levels) than long-period damping reduction factors, $\beta_{1}$. In effective damping amplitude independent (which is not generally true), the $5 \%$ damped spectrum would be reduced by the damping factors, as shown in Fig 5.

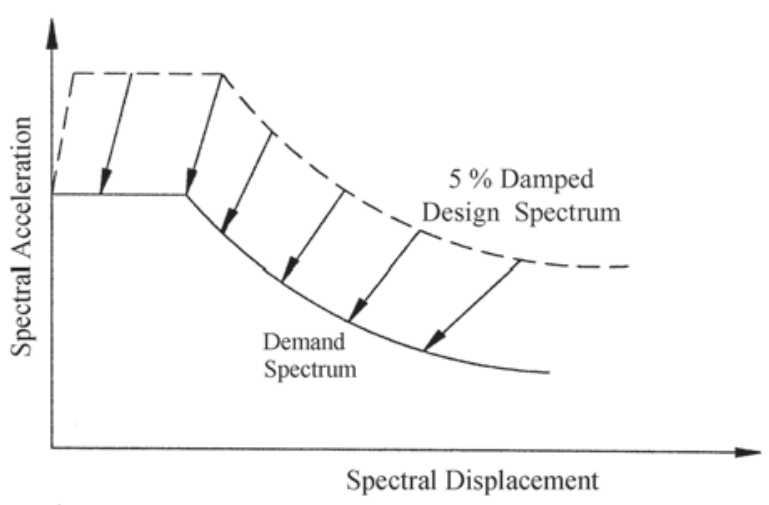

Fig 5. Demand spectrum construction

In general, effective period and effective damping are amplitude dependent. Up to yield, the effective period, $T_{\text {eff }}$ is the same as the initial period, $T_{i}$, and the effective damping, $\beta_{e f f}$ is equal to $5 \%$ of critical. After yield, effective period duration and effective damping typically increase as inelastic displacement of the structure increases.

In all cases, a unique value of effective damping can be calculated for each (spectral) displacement of the capacity curve. Damping reduction factors based on these values of effective damping may, in turn, be used to calculate a single "demand spectrum" curve from the $5 \%$ damped design spectrum of interest. This process is used to develop demand spectra that are then intersected with capacity spectra to determine the peak response of the system.

\section{The proposed multimode load pattern}

The multimode load pattern used in this research has already been proposed by the authors in other publications [12-14].

When a structure is subjected to an earthquake its linear elastic response will be a result of the combination of the modes of vibration with different participation factors:

$$
z=\sum_{i=1}^{n} z_{i}=\sum_{i=1}^{n} \varphi_{i} q_{i}
$$

where $\varphi_{i}$ are the modes of vibration of the structure and $q_{i}$ are the participation factors (time dependent).

The idea behind the combination of the modes for the pushover analysis is that the participation of each mode should be related with its influence on the behaviour of the structure at a predefined instant related with a specific response characteristic of the structure; this means that the load pattern will be a combination of the vibration mode shapes each one affected by a participation factor.

The first step in the procedure is to obtain the modes of vibration of the structure. The modes of vibration and the associated periods result from the eigenvalue analysis of the system, through the following equation:

$$
(K-\lambda M) \varphi=0,
$$

where $K$ is the stiffness matrix; $\lambda$ is the eigenvalue or natural frequency; $M$ is the mass matrix; and $\varphi$ is the eigenvector or vibration mode. Then the structural model is subjected to the seismic action associated with a real or a synthetic earthquake signal and the linear elastic response of the system is evaluated. This procedure is computationally easy and the software used in this research for these analyses was the SAP-2000 [15]. This package provides the individual response of the structure (displacement, base shear, energy) due to each mode of vibration, ie, it is possible to get the contribution of each mode for the global behaviour of the structure.

The global dynamic response of a structure, $R_{g}$, subjected to a ground motion excitation can be divided into modal contributions, $R_{i}$, using the equation

$$
R_{g}=\sum R_{i} .
$$

From these two parameters it is possible to define a participation factor $\alpha_{i}$, that will represent the contribution of each mode to the global response of the system using:

$$
\alpha_{i}=\frac{R_{i}}{R_{g}} .
$$

The dynamic behaviour of the majority of the structures is only affected by a small number of modes of vibration. For each dynamic analysis it is always necessary to define the number of modes that will be considered in the analysis $n_{\text {modes }}$. 
The new proposed load pattern (LP) will be proportional to the shape of the considered modes of vibration, each affected by the participation factor. The procedure to obtain the load pattern is defined in the following equation:

$$
L P=\alpha_{1} \varphi_{1}+\alpha_{2} \varphi_{2}+\ldots+\alpha_{n_{\text {modes }}} \varphi_{n_{\text {modes }}}=\sum_{i=1}^{n_{\text {modes }}} \alpha_{i} \varphi_{i} .(16)
$$

\section{Case studies}

The performance of the multi-modal load pattern proposed has been tested in several analyses. For that, the results of the pushover analysis performed with the multimode load pattern and with the load pattern based on the shape of the fundamental mode of vibration were compared with the results of the non-linear dynamic analysis. To guarantee a good performance, the new proposed multimode load pattern was tested in three different types of structures each with unique characteristics that represent different types of structural behaviour. All the structures analysed were of the three dimensional models [16]: (1) the symmetric structure; (2) the stiffness asymmetric structure; (3) the mass asymmetric structure.

For each structure, non-linear dynamic analysis with increasing seismic action (El Centro ground motion) was performed, ie, the structure was subjected to the same earthquake ground motion but with increasing magnitude level. In this way it was possible to achieve an ideal pushover envelope to be compared with the results of the static pushover analysis. The software utilised to perform the non-linear dynamic analysis was ADINA.

\subsection{The non-linear dynamic analysis model}

To perform the non-linear dynamic analysis of the structures the plastic-bilinear material model contained in ADINA software was chosen [7]. This material model is associated with the non-linear elasto-plastic beam element. During the analysis the beam element matrices are formulated using the Hermitian displacement functions. The elasto-plastic stress-strain relations are based on the classic flow theory with the von Mises yield condition.

The von Mises yield condition utilised for the stressstrain relation is illustrated in Fig 6 and can be obtained from the following equation:

$$
f_{y}^{t}=\frac{1}{2}\left(s^{t} \cdot s^{t}\right)-\frac{1}{3} \sigma_{y}^{2}=0,
$$

where $s^{t}$-deviatoric stress tensor; $\sigma_{y}-$ updated yield stress at time $t$.

For the non-linear beam elements used the element matrices were calculated applying numeric integration. The locations and the labelling of the integration points are shown in Fig 7.

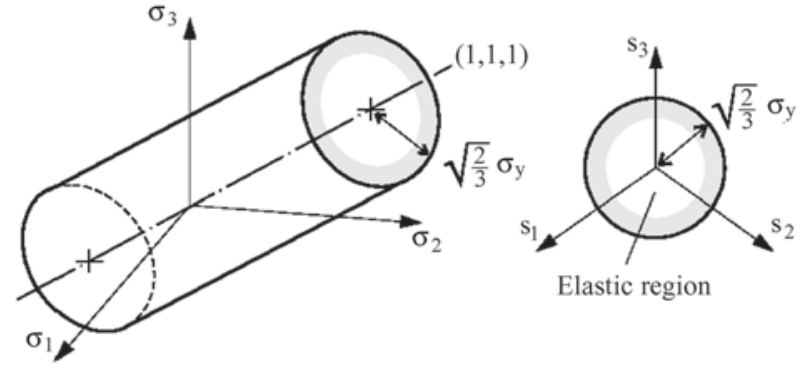

a) Principal stress space

b) Deviatoric stress space

Fig 6. The von Mises yield surface

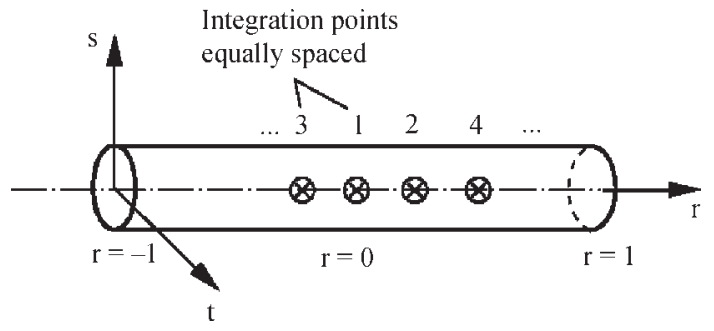

a) Integration point locations in r-direction

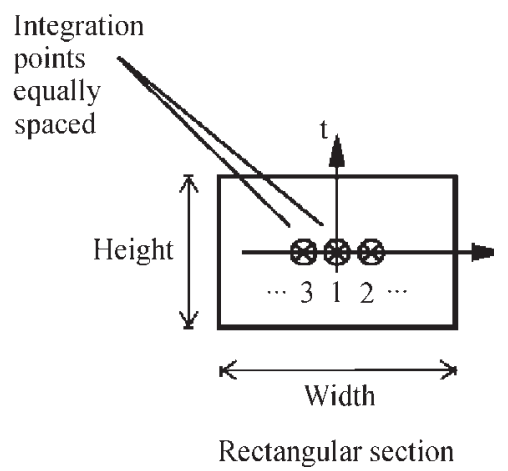

b) Integration point locations in s-direction

Fig 7. Location of the integration points

\subsection{The non-linear static pushover model}

The material model used in the static non-linear pushover analysis is based on the procedures proposed by the ATC-40 [1] and FEMA-273/274 [2] documents, defining force-deformation criteria for the hinges used in the pushover analysis. Fig 8 describes the typical forcedeformation relation proposed by those documents.

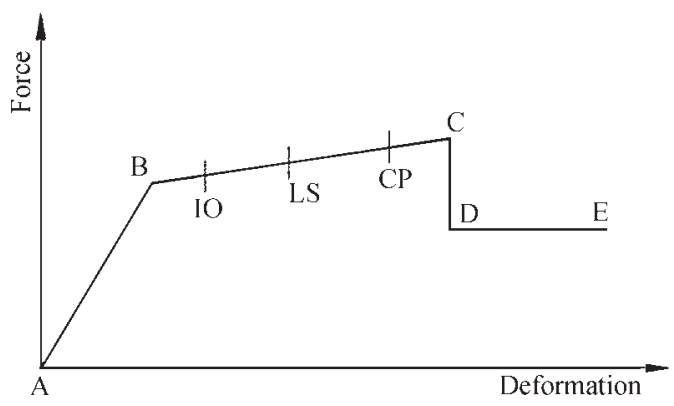

Fig 8. Force-deformation for pushover analysis 
Five points labelled $A, B, C, D$ and $E$ are used to define the force deflection behaviour of the hinge and three points labelled $I O, L S$ and $C P$ are used to define the acceptance criteria for the hinge $(I O, L S$, and $C P$ stand for Immediate Occupancy, Life Safety and Collapse Prevention respectively).

The hinges selected for the static non-linear pushover were the $P-M 2-M 3$ proposed by the above-mentioned documents. This type of hinges accounts for the interaction between the axial force and the bending moment on the behaviour of the structure. The interaction surface is defined by the user, and for the structural analyses of the three-dimensional models before-mentioned it was chosen the one presented in Fig 9. This interaction surface, proposed and used by several researchers in previous studies, is given by the interaction equation

$$
p^{2}+m^{2}+3,5 p^{2} m^{2}=1,
$$

where $\boldsymbol{P}_{\boldsymbol{y}}$ is the squash load and $\boldsymbol{M}_{\boldsymbol{y}}$ - the plastic moment.

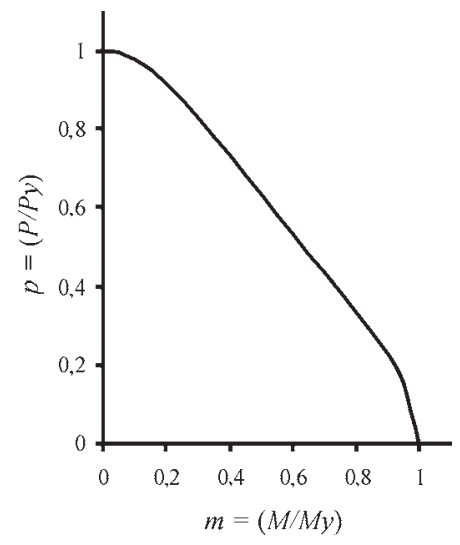

Fig 9. Interaction surface

\subsection{The results for distinct building frames}

To test and verify the reliability and performance of the multimodal load pattern several analyses were performed in three three-dimensional structural models [16]: the symmetric structure (Fig 10), the stiffness asymmetric structure (Fig 11) and the mass asymmetric structure (Fig 12). Some results of the comparative analyses, of symmetric and asymmetric three dimensional building frames, are presented in accordance with [12-14].

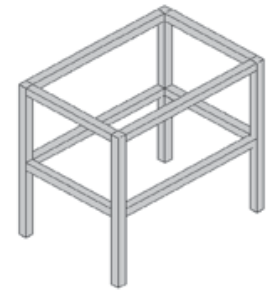

Fig 10. Symmetric structure

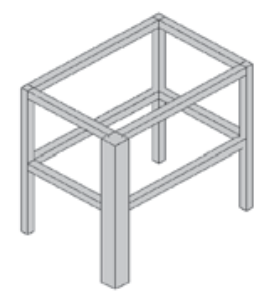

Fig 11. Stiffness asymmetric structure

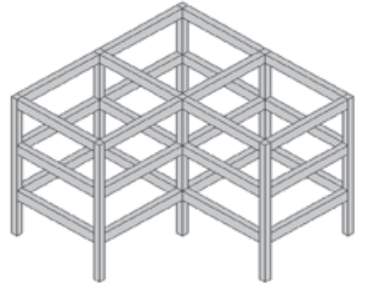

Fig 12. Mass asymmetric structure

Since the structures considered in this study were three-dimensional models, each one was analysed considering the seismic ground motion acting in different directions. In the following sections some results of those analyses are presented.

\subsubsection{The symmetric structure}

This structure responds primarily in its fundamental mode of vibration, so the multimodal load pattern coincides with the conventional load pattern based on the shape of the fundamental mode of vibration (Fig 13).

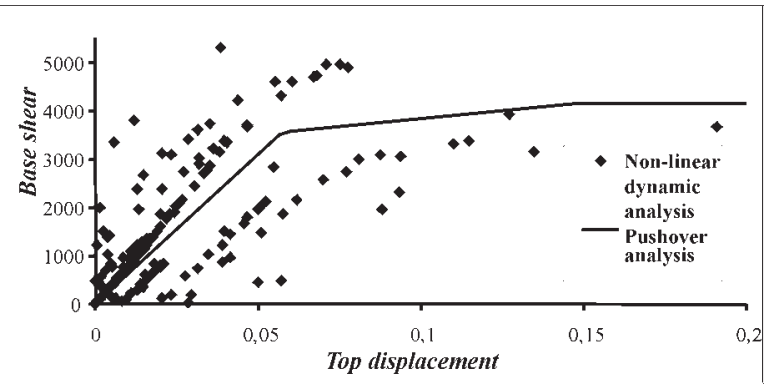

Fig 13. Results on the symmetric structure

\subsubsection{The stiffness asymmetric structure}

In this structure the higher modes of vibration are important for the global response of the system, particularly the torsional ones due to the stiffness asymmetry. So the structure was analysed for various directions of the ground motion in order to obtain a response dominated by the different modes of vibration (Figs 14, 15). The angles studied were: $-45^{\circ}, 0^{\circ}$ and $45^{\circ}$. With these three analyses the influence in the structural response of the various modes of vibration is taken into account for the comparison between pushover analysis with the multimodal load pattern and the non-linear dynamic analysis.

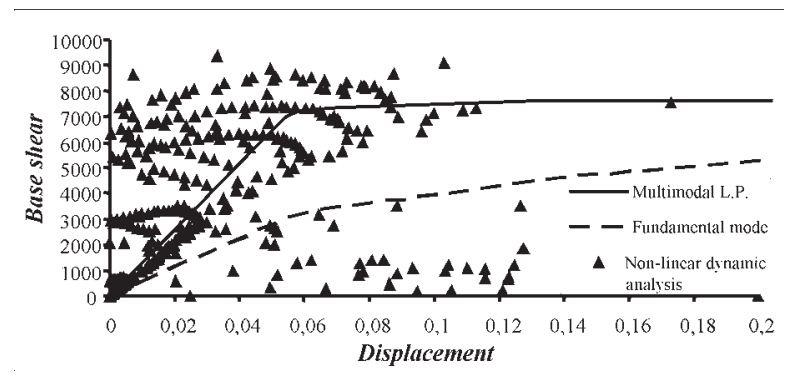

Fig 14. Stiffness asymmetric structure $\left(-45^{\circ}\right)$ 


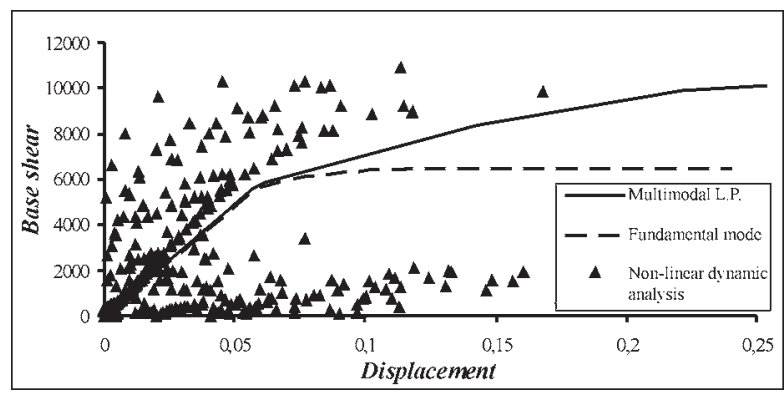

Fig 15. Stiffness asymmetric structure $\left(0^{\circ}\right)$

\subsubsection{The mass asymmetric structure}

This structural model is a more complex of the three analysed. Once again the higher modes of vibration are important for the global response of the system. During the research it became clear that the dynamic behaviour of this structure and the influence of each mode was strictly related to the direction of the earthquake ground motion, ie, the influence of the modes was directly proportional to the angle of the earthquake.

The earthquake ground motion was applied in three different directions $\left(0^{\circ}, 20^{\circ}, 45^{\circ}\right)$ and some results are outlined in Figs 16, 17.

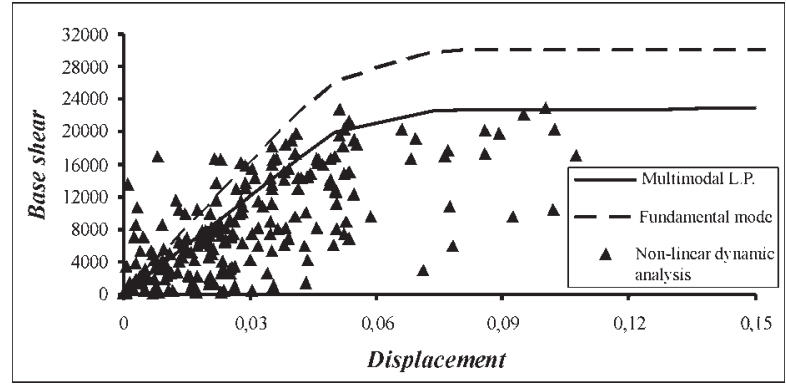

Fig 16. Mass asymmetric structure $\left(20^{\circ}\right)$

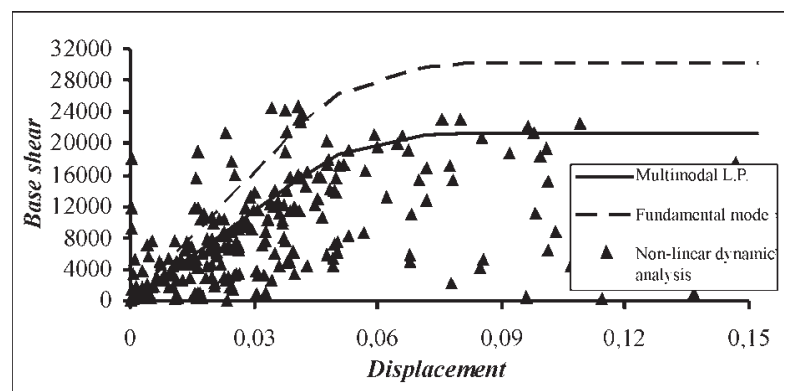

Fig 17. Mass asymmetric structure $\left(0^{\circ}\right)$

\section{Conclusions}

The performance of the pushover analysis in structures where higher modes of vibration are important for the total response of the system was investigated in this research. For that a multimodal load pattern based on the elastic response of the structure when subjected to a ground motion is proposed to account for the effect of the higher modes of vibration.
To conclude about the performance of the proposed load pattern, several analyses in three different structural models were carried out. The results of the pushover analysis of those structures with the proposed multimodal load pattern and with the conventional load pattern proportional to the shape of the fundamental mode of vibration of the system were compared with the non-linear dynamic analysis of the structures subjected to a ground motion with increasing severity, so that an ideal envelope for the pushover analysis was obtained. These are the conclusions drawn from those analyses:

- Pushover analysis is much easier and faster to implement than the non-linear dynamic one;

- When the dynamic behaviour of a structure is dominated by the fundamental mode of vibration, the result of the pushover analysis with the conventional load pattern proportional to the shape of the fundamental mode of vibration is very accurate. This can be observed in the results of the symmetric structure and of the mass asymmetric structure;

- For structures where the torsional modes of vibration are important for the global response of the structure the results with the proposed multimodal load pattern are much more accurate than the ones with the load pattern proportional to the shape of the fundamental mode of vibration. This statement is justified by the results of the stiffness asymmetric structure;

- In three-dimensional mass asymmetric structures with a dynamic response dominated by more than one mode of vibration, the performance of the pushover analysis with the proposed multimodal load pattern is very reliable and accurate. The pushover analysis with the load pattern proportional to the fundamental mode of vibration tends to overestimate the response of the system. This is observed in the results of the asymmetric mass structure;

- The performance level of the conventional pushover load pattern proportional to the shape of the fundamental mode of vibration decreases when higher modes of vibration became relevant to the total response of the system. In those situations the proposed multimodal load pattern becomes a useful tool;

- It will be necessary to perform some experimental studies to validate these computational results;

- From the evaluation of the results obtained in this research it is possible to conclude that the proposed multimodal load pattern improves the accuracy and reliability of the pushover analysis.

\section{References}

1. ATC. Seismic Evaluation and Retrofit of Concrete Buildings. Applied Technology Council, Report ATC-40, 1996.

2. FEMA. NEHRP Guidelines for the Seismic Rehabilitation of Buildings. FEMA-273. NEHRP Commentary on the Guidelines for the Seismic Rehabilitation of Buildings. 
FEMA-274. Federal Emergency Management Agency, Washington, D. C., 1997.

3. Bathe, K. J. Solution of Equilibrium Equations in Dynamic Analysis. Prentice Hall, Englewoods Cliffs, N. J., 1982.

4. Krawinkler, H. and Seneviratna, G. D. P. K. Pros and Cons of a Pushover Analysis of Seismic Performance Evaluation. Engineering Structures, Vol 20, Issues 4-6, April-June 1998, p. 452-464.

5. Mwafy, A. M. and Elnashai, A. S. Static Pushover Versus Dynamic Analysis of RC Buildings. Engineering Structures, Vol 23, Issue 5, May 2001, p. 407-424.

6. Almeida, R. F.; Caraslindas, H. P. and Carneiro Barros, R. Considerations on the Implementation of an Integrated Experimental System for Pseudo-Dynamic Structural Tests. Experimental Mechanics (Mecānica Experimental), No 9. Portuguese Association on Experimental Stress Analysis (APAET), LNEC, Lisbon, Portugal, 2003, p. 75-83 (in Portuguese).

7. ADINA R and D Inc. ADINA User's Manuals. Mass., USA, 1995.

8. Chopra, A. K. Dynamics of Structures: Theory and Application to Earthquake Engineering. Prentice Hall, Englewoods Cliffs, N. J., 1995.

9. SEAOC. Performance-Based Seismic Engineering of Buildings. Vision 2000 Report, Structural Engineers Association of California, Sacramento, CA, 1995.

10. SEAOC. Existing Nonductile Concrete Buildings and Division 95 of the Los Angeles City Building Code, Structural Engineers Association of California, Sacramento, CA, 1996.
11. Newmark, N. M. and Hall, W. J. Earthquake Spectra and Design. EERI - Earthquake Engineering Research Institute, CA, 1982.

12. Almeida, R. F. The Effect of Higher Modes of Vibration: Pushover Analysis vs Nonlinear Dynamic Analysis. MSc thesis, University of Glasgow, Scotland, 2002.

13. Almeida, R. F. and Carneiro Barros, R. Comparison Between Pushover Analysis and Non-linear Dynamic Analysis: the Importance of Higher Vibration Modes. In: Proc. of 7th Portuguese Congress on Applied and Computational Mechanics (VII Congresso de Mecānica Aplicada e Computacional). Ed. J. I. Barbosa, Vol I: Structural and Solid Mechanics (Mecānica dos Sólidos e Estrutural), Evora, Portugal, 2003, p. 239-248.

14. Almeida, R. F. and Barros, R. C. A New Multimode Load Pattern for Pushover Analysis: the Effect of Higher Modes of Vibration. In: Earthquake Resistant Engineering Structures IV, Ed.: G. Latini and C.A. Brebbia, WIT Press, U. K., 2003, p. 3-13.

15. CSi. Computers and Structures Inc., SAP 2000 - Static and Dynamic Finite Element Analysis of Structures. Berkeley, USA, 2001.

16. Faella, G. and Kilar, V. Asymmetric Multi-Storey R/C Frame Structures: Pushover Versus Nonlinear Dynamic Analysis. In: Proc. of $11^{\text {th }}$ European Conference on Earthquake Engineering, Sept 1998, Paris, France. Balkema, Rotterdam, 1998.

\section{SUPAPRASTINTA ASIMETRINIŲ ERDVINIU巳 STATYBINIŲ RĖMŲ DINAMINE ANALIZE்}

\section{R. C. Barros, R. Almeida}

Santrauka

Aukštesnių svyravimo formų efekto ịvertinimas, nagrinejjant bendrą konstrukcijos elgseną, yra labai svarbi dar neišspręsta problema. Uždaviniui supaprastinti pasiūlytas nesudètingas statinès netiesinès dinaminès analizès algoritmas, susietas su laikomosios galios spektriniu metodu, kai apkrovos modelis proporcingas bazinėms konstrukcijos svyravimo formoms. Supaprastintos dinaminès analizès rezultatai, gauti naudojant šị apkrovos modeli, yra labai tikslūs konstrukcijos atsakui pagal pirminę bazinę formą. Tačiau tais atvejais, kai tampa svarbi aukštesnių svyravimo formu įtaka bendram atsakui, šio apkrovos modelio taikymas yra netikslus. Uždaviniui minimizuoti siūlomas naujas daugiamodalinès apkrovos modelis, i̇vertinantis kiekvienos svyravimo formos santykini poveikị tampriam atsakui konstrukcijos, kurią veikia žemės drebėjimo sukelti pagrindo poslinkiai. Šis apkrovos modelis pritaikytas statybinių simetrinių rẻmų kuriuose veikia skirtingų krypčių seisminiai poveikiai, analizei, ìvertinant ir tuos atvejus, kai standumai ir masès yra asimetrinio pobūdžio. Atlikti analizès rezultatai apibendrinti svarbiomis išvadomis.

Raktažodžiai: supaprastinta dinaminè analizè, daugiamodalinės apkrovos modelis, netiesinė dinaminè analizė, asimetriškos ir nereguliarios konstrukcijos.

Rui Carneiro BARROS. Assoc Prof of Structural Engineering (Habilitation; PhD; MSc; Civil Engineer) at the Dept of Civil Engineering of 'FEUP: Faculdade Engenharia Universidade Porto -Portugal'. Full Member of 'OE: Ordem dos Engenheiros - Portugal' (Portuguese Society of Professional Engineers) and a member of OE Structural Specialisation Group. Member of ASCE and IABSE, as well as of the Portuguese Society of Earthquake Engineering. His actual research interests include the dynamic behaviour and the overall stability of buildings and special structures, particularly tanks, towers, masts and lifelines. He is professionally active also on strength and rehabilitation of old constructions.

Ricardo ALMEIDA. Reader of civil engineering in the Scholl of Technology at the Polytechnic of Viseu, Portugal. He is a member of 'OE: Ordem dos Engenheiros - Portugal' (Portuguese Society of Professional Engineers). His research interests include the pushover analysis of structures and the dynamic behaviour of steel masts. 